\title{
Special issue on institutional theory in information systems research: contextualizing the IT artefact
}

\author{
Journal of Information Technology (2009) 24, 283-285. doi:10.1057/jit.2009.17
}

W e are pleased to introduce this special issue of the Journal of Information Technology on Institutional Theory in Information Systems (IS) Research. The publication of The New Institutionalism in Organizational Analysis (Powell and Dimaggio, 1991) and Institutions and Organization (Scott, 2001) were significant contributions to the renaissance in the study of institutions in the social sciences (Dimaggio and Powell, 1991). These influential books remind us that institutionalism is a highly complex field, where work is delineated across core disciplines, including economics, sociology, political science, history and ecology. To add to the complexity and richness of the theory, contributions have been divided into time frames labelled the 'old' and 'new' institutionalism (Greenwood et al., 2008). These authors suggest the conceptual foundations of 'organisational institutionalism' were established between 1977 and 1983 with seminal works by Meyer and Rowan (1977), Zucker (1977), Dimaggio and Powell (1983), Meyer and Scott (1983) and Zucker (1983).

Between 1983 and 1991, institutional studies acknowledged that social values affect organizations and that organizations adopt structures for legitimation purposes. Yet, few attempts were made to test 'institutional ideas', and citations to the seminal papers were sparse (Greenwood et al., 2008). What was apparent was that many studies relating to institutionalized organisations' were located in the government and notfor-profit sector, thus overlooking that the 'markets' and private sector firms were also influenced by institutionalized effects and processes. Another observation was that organizations were often portrayed as 'too passive', so the theory was criticized as lacking an 'agency' dimension to understanding and explaining social phenomena.

Since the early 1990s, institutional theory has gained momentum in the social sciences despite continuing ambiguity about concepts such as institution, institutionalization and institutionalism, and how both macro- and microinstitutional influences can be reconciled within a single study. In an effort to provide conceptual clarity, Jepperson (1991: 145 and 152) offered the following definitions: institution is 'a social order or pattern that has attained a certain state or property'; institutionalization, 'denotes the process of such attainment'; and Institutionalism, is 'a theoretical strategy that features institutional theories and seeks to develop and apply them'. Two additional concepts further emerged within the institutional theory literature.
Deinstitutionalization is 'the erosion or discontinuity of an institutionalized organizational activity or practice' (Oliver, 1992: 563) and reinstitutionalization, represents an 'exit from one institutionalization, and entry into another institutional form, organized around different principles or rules' (Jepperson, 1991: 152).

The last two decades have witnessed increased use of institutionalist concepts, such as legitimacy, logics and isomorphism. Suchman's (1995) study distinguished among pragmatic, moral and cognitive legitimacy. Others called for better empirical measures to evaluate and test legitimacy (Zucker, 1987). Work on institutional logics further flourished, with some writers cautioning against using the term as a 'buzzword' (Thornton and Ocasio, 2008). Institutional isomorphism, for example a commonality in form and function (Dimaggio and Powell, 1991) generated renewed interest from researchers with work emphasizing the processual and transmission studies of earlier decades (Greenwood et al., 2008). More recently, work has emerged which is a departure from prior work on institutional persistence and isomorphism to explore new ideas on institutional entrepreneurship and change (Garud et al., 2002; Hardy and Maguire, 2008). The impetus for much of this work is to explore how and why agency plays a part in altering institutionalized patterns of behaviour.

Characterized by epistemological pluralism and conceptual ambiguity, institutional theory has emerged as an important set of concepts and ideas for researchers across the disciplines. In the past decade, the IS field has seen a growing interest in institutional theory. These contributions are varied, with many studies using institutionalist concepts as a lens to interpret and analyse data, and fewer seeking to extend our theoretical understanding of institutionalism. With the exception of contributions that examine the relationship between technology and institutions (Barley, 1986; King et al., 1994; Orlikowski and Barley, 2001), IS that work using institutional theory has included topics on adoption and diffusion, development and implementation and structural changes across societal and industrial sectors, notably, SMEs, manufacturing, health and financial services.

This Special Issue recognizes and promotes the relevance and richness of institutional theory in IS research. It questions the rhetoric that serves to isolate the IT artefact 
Table 1 Five case studies

\begin{tabular}{|c|c|c|c|c|c|}
\hline Author(s) & Study subject & Study approach & $\begin{array}{l}\text { Institutional } \\
\text { time frame }\end{array}$ & $\begin{array}{l}\text { Theoretical } \\
\text { perspective }\end{array}$ & Findings \\
\hline $\begin{array}{l}\text { Lyytinen, K., } \\
\text { Newman, M., Al } \\
\text { Muharfi, A.A.R. }\end{array}$ & $\begin{array}{l}\text { ERP implementation } \\
\text { at Saudi Steel }\end{array}$ & $\begin{array}{l}\text { Realist } \\
\text { ethnographic }\end{array}$ & 1992-2004 & $\begin{array}{l}\text { Punctuated model of } \\
\text { socio-technical change }\end{array}$ & $\begin{array}{l}\text { Why } \\
\text { institutionalization is } \\
\text { difficult and unfolds in } \\
\text { unpredictable ways }\end{array}$ \\
\hline $\begin{array}{l}\text { Rajao, R.G.L., } \\
\text { Hayes, N. }\end{array}$ & $\begin{array}{l}\text { Uses of Amazon } \\
\text { rainforest } \\
\text { monitoring system }\end{array}$ & Interpretive & 1964-2008 & Conceptions of control & $\begin{array}{l}\text { IT artifacts can both } \\
\text { reflect the current } \\
\text { dominant conception } \\
\text { and support alternate } \\
\text { conceptions }\end{array}$ \\
\hline $\begin{array}{l}\text { Nicholson, B., } \\
\text { Sahay, S. }\end{array}$ & $\begin{array}{l}\text { Software export } \\
\text { policymaking in } \\
\text { Costa Rica }\end{array}$ & Action research & $2002-2006$ & Deinstitutionalization & $\begin{array}{l}\text { How dissensus forms } \\
\text { to destabilize norms } \\
\text { and activities }\end{array}$ \\
\hline $\begin{array}{l}\text { Jensen, T.B., } \\
\text { Kjaergaard, A., } \\
\text { Svejvig, P. }\end{array}$ & $\begin{array}{l}\text { EPR system } \\
\text { implementation in a } \\
\text { Danish hospital ward }\end{array}$ & Interpretive & 2000-2007 & $\begin{array}{l}\text { Combining institutional } \\
\text { and sense-making } \\
\text { theories }\end{array}$ & $\begin{array}{l}\text { How a rationalized } \\
\text { myth travels from field } \\
\text { to ward to doctors }\end{array}$ \\
\hline
\end{tabular}

as a unit of analysis, and instead recognizes the importance of contextualizing IT within the wider socio-economic and political landscape (Currie, 2009). Our aim is to publish papers that deploy institutional concepts to analyse and interpret the adoption or diffusion of IT, and also to strengthen the intersection between IS and related fields, including organization science, accounting, entrepreneurship and public administration.

The issue includes seven articles, five of which report on case studies of the institutionalization of IT, each in a different national context, and two of which report on analyses of the already published literature. It thus offers the reader both a set of current research on the subject and a window through which to view prior work to date.

The five case studies comprise a diverse group and are briefly summarized for comparison purposes in Table 1 . Two of the five address the familiar topic of implementation of application systems, one ERP (Enterprise Resource Planning) at Saudi Steel and one EPR (Electronic Patient Records) at a Danish hospital. A third is topically closely related, addressing the 'imbedding' of a new electronic infrastructure, an intranet, at a British Bank. Two venture further from the norm. One examines the life of an IT system, a rainforest monitoring system, over more than 40 years, marked by significant social and political change. A second is similarly anchored in social and political context, examining the process of deinstitutionalization in software export policymaking in Costa Rica.

Three of the five case studies employed an interpretive approach, now widely used among IS researchers. A fourth took what the authors term a 'realist ethnographic' approach. The fifth reports on action research. All make use of similar and familiar sources for their data, with interviewing serving as the dominant method, supplemented in varying degrees by other means, such as participant observation and direct engagement, including the use of focus groups and the gathering and examination of related organizational documents.

We were particularly interested to reflect on the role played by time frames in the five case studies. The first frame pertained to that of the institutional process associated with the subject of study, and is seen to range from a minimum of 5 years (in the case of software export policy making in Costa Rica) to 44 years (in the case of the Amazon rainforest monitoring system). Two studies (the imbedding of the intranet at the British bank and the EPR system implementation in the Danish hospital ward) employed institutional time frames of 7 and 8 years, respectively, while the other (the ERP implementation at Saudi Steel) used a 13-year frame. On the whole, the suggestion is that where the use of IT is concerned, institutional processes span time periods of significant length, more than might be expected by those impressed with rapid changes in the technology itself.

The second time frame pertained to the researchers' own period of data-gathering engagement in the study. This ranged from 1 year (in the study of the EPR system implementation in the Danish hospital ward) to 5 years (in the action research undertaken on software export policy making in Costa Rica). We draw attention to these time frames to highlight the challenges associated carrying out institutional research of the case study type reported here, where the period of researcher engagement is typically more abbreviated than, and often only imbedded within, the time frame associated with the institutional process under study and theorization, a process which may in fact 
still be unfolding. At one extreme, the researcher may largely be acting as a historian (as with the report on the Amazon rainforest monitoring systems), looking back over the years at events that shaped institutionalization. At the other extreme, the researcher may be both an observer and key player in a contemporary set of events (as in the study of software export policy making in Costa Rica), seeking understanding in real time, even before the event chain has concluded.

Time frames play a role too in the pair of articles analysing the already published literature in institutional theory applied to the IS context. In both studies, the method of looking back at the literature generated reviews with distinctive time horizons. The different methods also yielded contrasting sets of articles. Weekakkody, Dwivedi G.R., Irani, Z. begin by looking back in effect some 30 years in identifying 511 articles on institutional theory in the broader literature (the oldest article being published in 1978), before identifying and categorizing 28 articles published since 1999 that engage institutional theory in an IS/IT context. Mignerat and Rivard, in contrast, used a very different method to identify and describe 53 published articles that employed an institutional perspective in studying IS/IT phenomena. Although the majority of their article set is also quite recent and overlaps those identified in the other review, one article (by Klein and Hirschheim) dates back to 1989, some 20 years ago. We leave it as an exercise for the reader to enumerate the overlap in the two useful reviews.

The articles presented in this special issue offer a rich picture of institutional work with case studies obtained from the UK, Middle East, South America and Scandinavia. The two review articles were conducted by researchers based in the UK and Canada, respectively. As the body of work on institutional theory grows, we take on board some of the concerns of Greenwood et al. (2008), which imply that the richness and diversity of institutional concepts pose both the strength and weakness. Powerful institutionalist concepts like coercive, normative and mimetic isomorphism have been widely used by social science researchers, sometimes as a 'catch-all' to explain social phenomena, often ignoring debates that conceptual ambiguity about their exact meaning continue to be discussed in the literature.

Despite the shortcomings of institutional theory, this issue responds to calls for more process-oriented studies and combinations with, or incorporation of, other theories (e.g. sensemaking). A large body of work considers institutional effects, with fewer studies on institutional processes (Currie, 2009). Our five cases studies and two review articles contribute to the field through avoiding the charge of ethnocentrism, as our authors present their work from different geographical and epistemological standpoints. As for the field of IS, we hope this special issue demonstrates that institutional effects and processes pertaining to IT can be understood from a multi-level analysis that extends beyond the organization to the field and societal levels.

Wendy L Currie and E Burton Swanson

\section{References}

Barley, S. (1986). Technology as an Occasion for Structuring: Evidence from observations of CT scanners and the social order of radiology departments, Administrative Science Quarterly 31(1): 78-108.

Currie, W. (2009). Contextualising the IT Artifact: Towards a wider research agenda for IS using institutional theory, Information Technology \& People 22(1): 63-77.

Dimaggio, P.J. and Powell, W.W. (1983). The Iron Cage Revisited: Institutional isomorphism and collective rationality in organizational fields, American Sociological Review 48: 147-160.

DiMaggio, P.J. and Powell, W.W. (1991). Introduction, in W.W. Powell and P.J. DiMaggio (eds.) The New Institutionalism in Organizational Analysis, Chicago: University of Chicago Press.

Garud, R., Jain, S. and Kumaraswamy, A. (2002). Institutional Entrepreneurship in the Sponsorship of Common Technological Standards: The case of Sun Microsystems and Java, Academy of Management Journal 45: 114-196.

Greenwood, R., Oliver, C., Sahlin, K. and Suddaby, R. (2008). The SAGE Handbook of Organisational Institutionalism, London: Sage.

Hardy, C. and Maguire, S. (2008). Institutional Entrepreneurship, in R. Greenwood, C. Oliver, K. Sahlin and R. Suddaby (eds.) The SAGE Handbook of Organisational Institutionalism, London: Sage, pp. 198-242.

Jepperson, R.L. (1991). Institutions, Institutional Effects, and Institutionalism, in W.W. Powell and P. DiMaggio (eds.) The New Institutionalism in Organizational Analysis, Chicago: University of Chicago Press, pp. 143-163.

King, J.L., Gurbaxani, V., Kraemer, K.L., McFarlan, F.W., Raman, K.S. and Yap, C.S. (1994). Institutional Factors in Information Technology Innovation, Information Systems Research 5(2): 139-169.

Meyer, J.W. and Rowan, B. (1977). Institutionalized Organizations: Formal structure as myth and ceremony, American Journal of Sociology 83(2): 340-363.

Meyer, J.W. and Scott, W.R. (1983). Organizational Environments. Beverly Hills, CA: Sage Publications.

Oliver, C. (1992). The Antecedents of Deinstitutionalization, Organization Studies 13: 563-588.

Orlikowski, W.J. and Barley, S.R. (2001). Technology and Institutions: What can research on information technology and research on organizations learn from each other? MIS Quarterly 25(2): 145-165.

Powell, W.W. and DiMaggio, P. (eds.) (1991). The New Institutionalism in Organizational Analysis, Chicago: University of Chicago Press, pp. 183-203.

Scott, W.R. (2001). Institutions and Organizations, 2nd edn, USA: Sage Publications.

Suchman, M.C. (1995). Managing Legitimacy: Strategic and institutional approaches, Academy of Management Review 20: 571-610.

Thornton, P.H. and Ocasio, W. (2008). Institutional Logics, in R. Greenwood, C. Oliver, K. Sahlin and R. Suddaby (eds.) The SAGE Handbook of Organisational Institutionalism, London: Sage, pp. 130-148.

Zucker, L.G. (1977). The Role of Institutionalization in Cultural Persistence, American Sociological Review 42(5): 726-743.

Zucker, L.G. (1983). Organizations as Institutions, in S.B. Bacharach (ed.) Research in the Sociology of Organizations, Greenwich, CT: JAI Press, pp. 1-42.

Zucker, L.G. (1987). Institutional Theories of Organizations, Annual Review of Sociology 13: 443-464. 